\title{
Failure Mode Superposition Approach To Structural Appraisal of a Building during Construction
}

\author{
Sule Samuel \\ Faculty of Infrastructure Systems Engineering, University of Port Harcourt, P.M.B 5323, Rivers State, Nigeria
}

\begin{abstract}
The reliability of the concrete components in any civil engineering structure is a function of the reliability of the individual components that make up the structure. In this paper, a simple failure mode superposition approach is invoked in the estimation of reliability indices of all the concrete components of an ongoing construction. The probability of failure of concrete components in the structure is assumed to be the superposition of the probability of failure of the individual components of the entire structure. The strength parameters employed in this study was obtained from the non-destructive test that was carried out on the concrete components of the laboratory Block at college of Continuing Education, University of Port Harcourt, Nigeria. The safety index value for the structure obtained from the formulated model was 2.54 which was compared with the code specified values for the various structural members involved. It was found to be less than 4.9 for beams in bending or flexure, 3.6 for beams in shear, 4.5 for slabs and 3.9 for columns under deadlive load combination showing that the structure cannot perform satisfactorily in service and may cause loss of lives and damage of properties on collapse.
\end{abstract}

\section{Introduction}

Any engineered structure must fulfil the intended purpose, must be safe and must be economical both in terms of construction and maintenance costs [1]. The safety factors used in conventional design is no guarantee for structural safety due to uncertainties that occur in structural loadings [2-5]. The reliability evaluation of engineered structures is a task of paramount importance structural engineers both at the design stage and during construction to achieve satisfactory performance of the structure in service. This improves structural durability, structural quality and avoids loss financing [6-8]. Signs of structural distress such as visible cracks noticed on a structure, vibration of floors when subjected to human induced excitation during after construction are common reasons for safety assessment [9-10]. Due to uncertainties that occur in structural loading, the probabilistic concept becomes a useful tool. Probabilistic probabilities theory may not provide answers to all issues of unknown in the design models but has played a very remarkable role in the safety assessment of most engineering structures [10].

It is not only in Engineering that we have quackery, we also have quacks in the safety profession and other professions. According to the $28^{\text {th }}$ President of the Nigerian Society of Engineers, Engr. Mustafa Balarabe Shehu [11], only enforcement of the Engineering regulation act and creation of awareness on skills of professional engineers will eliminate quackery in the system and indeed in professional practice in other disciplines.

In this paper, failure mode superposition model is formulated to evaluate the safety of an ongoing construction. The algorithm involved is simple and straight forward and can be achieved manually.

\section{Formulation Of Failure Mode Superposition Model}

C onsider a three-storey frame consisting of beams, slabs, columns and footings as shown in Figure 1. The structure is assumed to be a series system with m modes of failure with the failure of any of the structural components causing the failure of the entire structure.

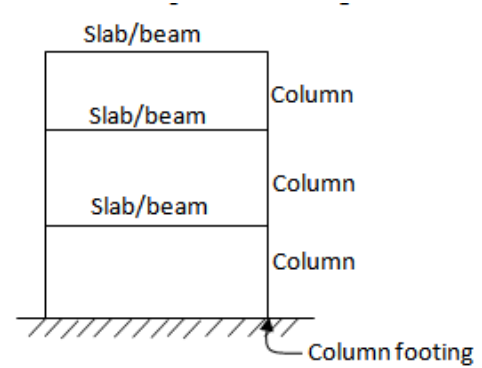

Figure 1: A three- storey structural arrangement 
From Figure 1, the limit state function for a particular failure mode $\mathrm{i}$ is given by:

$$
\begin{gathered}
g_{i}(x)=g_{i}\left(x_{1}, x_{2}, \ldots, x_{n}\right) \\
(i=1,2, \ldots, m)
\end{gathered}
$$

Where:

$x_{i}(i=1,2, \ldots, n)$ represents the basic variables which are assumed to vary randomly and stochastically.

$g_{i}\left(x_{i}\right)=$ limit state function.

The failure scenario for a particular mode $\mathrm{i}$ is defined as:

$F_{i}=\left[g_{i}(x) \leq 0\right]$

The structure is assumed to behave as a series system with the failure of one component affecting the satisfactory performance of the entire structure. The failure scenario of the structure is therefore given by:

$$
F=F_{1} \cup F_{2} \cup \ldots \cup F_{m}
$$

From Figure 1 and using equation (3), the probability of failure of the entire structure is given by:

$$
\begin{gathered}
p_{f}=p\left[\left(B_{1} \cap B_{2}\right) \cup\left(B_{2} \cap B_{3}\right) \cup\left(S_{L 1} \cap S_{L 2}\right) \cup\left(S_{L 2} \cap S_{L 3}\right) \cup\left(C_{1} \cap C_{2}\right) \cup\left(C_{2} \cap C_{3}\right)\right. \\
\left.\cup\left(F_{T 1} \cap F_{T 2}\right) \cup\left(F_{T 2} \cap F_{T 3}\right)\right]
\end{gathered}
$$

Where:

$B_{i}(i=1,2,3), S_{L i}(i=1,2,3), C_{i}(i=1,2,3), F_{T i}(i=1,2,3)=$ Beams, slabs, columns and footing of the structure respectively

$\mathrm{P}=$ probability operator.

According to Melcher [1], if the structure (Figure 1) is subjected to a sequence of structural loadings and the structure fails in any one or more of a number of possible modes of failure under any loading in the loading sequence, then using equation (4), the probability of failure of the entire structure can be written as:

$P_{F T}=P\left(F_{1}\right) \cup P\left(F_{2} \cap S_{1}\right) \cup P\left(F_{3} \cap S_{2} \cap S_{1}\right) \cup P\left(F_{4} \cap S_{3} \cap S_{2} \cap S_{1}\right) \cup \ldots$

Where:

$F_{i}(i=1,2,3,4, \ldots, n)$ represents structural failure scenario in a particular failure mode for all structural loading.

$S_{i}(i=1,2,3, \ldots, n)$ represents the survival of the structure in a particular mode under all structural loading.

From probability theory,

$P\left(F_{2} \cap S_{1}\right)=P\left(F_{2}\right)-P\left(F_{2} \cap F_{1}\right)$

Using equation (3), equation (2) can be written as:

$$
\begin{gathered}
P(F)=P\left(F_{1}\right)+P\left(F_{2}\right)-P\left(F_{1} \cap F_{2}\right)+P\left(F_{3}\right)-P\left(F_{1} \cap F_{3}\right) \\
-P\left(F_{2} \cap F_{3}\right)+P\left(F_{1} \cap F_{2} \cap F_{3}\right)+\ldots
\end{gathered}
$$

Where:

$\left(F_{i} \cap F_{j}\right)$ represents failure scenario in mode $\mathrm{i}$ and $\mathrm{j}$.

The generalized form of equation (4) for $\mathrm{m}$ failure scenario can be written as:

$$
\begin{gathered}
P_{f}=\sum_{i=1}^{m} P\left(F_{i}\right)-\sum_{1 \leq i \leq j \leq m} P\left(F_{i} \cap F_{j}\right)+\sum_{1 \leq i<j<k \leq m} \sum_{k} P\left(F_{i} \cap F_{j} \cap F_{k}\right) \\
+\ldots .+(-1)^{m-1} P\left(F_{1} \cap F_{2} \cap \ldots \cap F_{m}\right)
\end{gathered}
$$

If $P_{f i}<<1$, then $P\left(F_{i} \cap F_{j}\right)$ and $P\left(F_{i} \cap F_{j} \cap F_{k}\right)$

are negligible and equation $(8)$ reduces to:

$$
P(F)=\sum_{i=1}^{m} P_{f_{i}}
$$

For satisfactory performance of the component members,

$P_{s}=P\left(B_{i} \cap S_{L i} \cap C_{i} \cap F_{m i}\right)$

For $\mathrm{m}$ independent failure modes,

$P_{s}=\left(1-P\left(F_{B i}\right)\left(1-P\left(S_{L i}\right)\left(1-P\left(F_{C i}\right)\left(1-P\left(F_{T i}\right) \ldots\left(1-P\left(F_{m i}\right)\right.\right.\right.\right.\right.$

Equation (11) can be written as: 


$$
P_{s}=\prod_{i=1}^{m}\left[1-P_{f_{m c i}}\right]
$$

Where:

$P_{f_{m c i}}(i=1,2,3, \ldots, m)=$ probability of failure of component members.

Using equation (12),

$$
\left.P_{f}=1-\prod_{i=1}^{m}\left[1-P_{f_{m c i}}\right)\right]
$$

Equation (13) represents the probability of failure of the structural system.

According to From BS8110 [12],

$$
\mu_{x}=0.67 \mu_{y}
$$

Where:

$\mu_{x}, \mu_{y}=$ Mean value of concrete strength in structure and cube strength of concrete respectively.

According to Ranganatham [2], the coefficient of variation of concrete strength is a square root of sum of squares value given by:

$\delta_{x}=\left(\delta_{y}^{2}+\delta_{\text {test }}^{2}+\delta_{\text {in-situ }}^{2}\right)^{1 / 2}$

According to Ranganathan [2],

$\delta_{\text {test }}=\delta_{\text {in-situ }}=0.10$

From equation (15) we have:

$\delta_{x}=\left(\delta_{y}^{2}+0.125\right)^{1 / 2}$

Where:

$\delta_{\text {test }}, \delta_{\text {in-situ }}=$ variation of strength of concrete resulting from testing procedure and in-situ variation of concrete strength respectively.

The value of $\delta_{y}$ is a function of the mix design

For an ith structural component to perform satisfactorily in service,

$M_{i}=R_{i}-Q_{i}>0$

where:

$M_{i}=$ safety margin of an ith structural component

$R_{i}=$ strength of a jth structural component.

$Q_{i}=$ load on a jth structural component.

The probability of failure of $j$ th structural component is given by:

$P_{f_{i}}=P\left(X_{i}<f_{a}\right)$

Where:

$X_{i}(i=1,2, \ldots, n)=$ random variable representing strength of ith structural component.

$f_{a}=$ Allowable compressive stress of concrete.

From BS8110 [12],

$f_{a}=0.37 f_{c u}$

Using equation (19), the probability of failure corresponding to an ith failure mode is given by:

$P_{f i}=\phi\left(\frac{f_{a}-\mu_{x i}}{\sigma_{x i}}\right) ; i=1,2, \ldots, n$

Where:

$\beta_{i}=\left(\frac{f_{a}-\mu_{x i}}{\sigma_{x i}}\right)$

Equation (22) gives the value of safety index for a particular structural member and it represents the minimum distance from the origin to the failure surface. 
III. Results And Discussion

Table 1: Results of non-destructive test on concrete [13]

\begin{tabular}{|l|l|c|c|c|}
\hline S/No & \multicolumn{1}{|c|}{ Location } & $\begin{array}{c}\text { Rebound } \\
\text { Hammer } \\
\text { readings }\end{array}$ & $\begin{array}{c}\text { Average } \\
\text { Rebound }\end{array}$ & $\begin{array}{c}\text { Concrete Strength from } \\
\text { Rebound } \\
\text { Test (y) }\end{array}$ \\
\hline 1 & Middle panel & 23,23 & 23 & 18 \\
\hline 2 & Edge panel & 23,23 & 23 & 18 \\
\hline 3 & Slab 2 & 24,24 & 24 & 20 \\
\hline 4 & Staircase & $23.3,19$ & 21.2 & 15 \\
\hline 5 & Middle column & 35,27 & 31 & 29 \\
\hline 6 & Corner column & 27,27 & 27 & 25 \\
\hline
\end{tabular}

Table 2: Statistics of basic variable at middle and edge panel [2]

\begin{tabular}{|l|l|c|c|c|c|c|c|}
\hline Variable & Mix & $\begin{array}{l}\text { Specified } \\
\text { strength }\end{array}$ & $\begin{array}{c}\text { Mean } \\
\left(\mu_{y}\right) \mathrm{N} / \mathrm{mm}^{2}\end{array}$ & $\begin{array}{c}\text { Std } \\
\left(\sigma_{y}\right) \mathrm{N} / \mathrm{mm}^{2}\end{array}$ & $\begin{array}{c}\text { Cov } \\
\left(\delta_{y}\right) \%\end{array}$ & $\begin{array}{l}\text { Probability } \\
\text { distribution }\end{array}$ & $\begin{array}{l}\text { Quality } \\
\text { control }\end{array}$ \\
\hline $\begin{array}{l}\text { Cube } \\
\text { strength }\end{array}$ & M18 & 18 & 22.18 & 3.37 & 15.20 & Normal & $\begin{array}{l}\text { design } \\
\text { mix }\end{array}$ \\
\hline
\end{tabular}

Table 3: Statistics of basic variable staircase [2]

\begin{tabular}{|l|l|l|c|c|c|c|l|}
\hline Variable & Mix & $\begin{array}{l}\text { Specified } \\
\text { strength }\end{array}$ & $\begin{array}{c}\text { Mean } \\
\left(\mu_{y}\right) \mathrm{N} / \mathrm{mm}^{2}\end{array}$ & $\begin{array}{c}\text { Std } \\
\left(\sigma_{y}\right) \mathrm{N} / \mathrm{mm}^{2}\end{array}$ & $\begin{array}{c}\text { Cov } \\
\left(\delta_{y}\right) \%\end{array}$ & $\begin{array}{l}\text { Probability } \\
\text { distribution }\end{array}$ & $\begin{array}{l}\text { Quality } \\
\text { control }\end{array}$ \\
\hline $\begin{array}{l}\text { Cube } \\
\text { strength }\end{array}$ & M15 & 15 & 17.56 & 2.69 & 15.33 & Normal & $\begin{array}{l}\text { design } \\
\text { mix }\end{array}$ \\
\hline
\end{tabular}

Table 4: Statistics of basic variable at slab 2 [2]

\begin{tabular}{|l|l|c|c|c|c|c|l|}
\hline Variable & Mix & $\begin{array}{c}\text { Specified } \\
\text { mix }\end{array}$ & $\begin{array}{c}\text { Mean } \\
\left(\mu_{y}\right) N / \mathrm{mm}^{2}\end{array}$ & $\begin{array}{c}\text { Std } \\
\left(\sigma_{y}\right) \mathrm{N} / \mathrm{mm}^{2}\end{array}$ & $\begin{array}{c}\text { Cov } \\
\left(\delta_{y}\right)\end{array}$ & $\begin{array}{l}\text { Probability } \\
\text { distribution }\end{array}$ & $\begin{array}{l}\text { Quality } \\
\text { control }\end{array}$ \\
\hline $\begin{array}{l}\text { Cube } \\
\text { strength }\end{array}$ & M20 & 20 & 26.80 & 4.04 & 15.07 & Normal & $\begin{array}{l}\text { design } \\
\text { mix }\end{array}$ \\
\hline
\end{tabular}

Table 5: Statistics of basic variable at corner column [2]

\begin{tabular}{|l|l|c|c|c|c|c|l|}
\hline Variable & Mix & $\begin{array}{c}\text { Specified } \\
\text { mix }\end{array}$ & $\begin{array}{c}\text { Mean } \\
\left(\mu_{y}\right) N / \mathrm{mm}^{2}\end{array}$ & $\begin{array}{c}\text { Std } \\
\left(\sigma_{y}\right) \mathrm{N} / \mathrm{mm}^{2}\end{array}$ & $\begin{array}{c}\text { Cov } \\
\left(\delta_{y}\right)\end{array}$ & $\begin{array}{l}\text { Probability } \\
\text { distribution }\end{array}$ & $\begin{array}{l}\text { Quality } \\
\text { control }\end{array}$ \\
\hline $\begin{array}{l}\text { Cube } \\
\text { strength }\end{array}$ & M25 & 25 & 30.28 & 3.77 & 12.45 & Normal & $\begin{array}{l}\text { design } \\
\text { mix }\end{array}$ \\
\hline
\end{tabular}

Table 6: Statistics of basic variable at middle column [2]

\begin{tabular}{|l|l|c|c|c|c|c|l|}
\hline Variable & Mix & $\begin{array}{c}\text { Specified } \\
\text { mix }\end{array}$ & $\begin{array}{c}\text { Mean } \\
\left(\mu_{y}\right) \mathrm{N} / \mathrm{mm}^{2}\end{array}$ & $\begin{array}{c}\text { Std } \\
\left(\sigma_{y}\right) \mathrm{N} / \mathrm{mm}^{2}\end{array}$ & $\begin{array}{c}\text { Cov } \\
\left(\delta_{y}\right)\end{array}$ & $\begin{array}{l}\text { Probability } \\
\text { distribution }\end{array}$ & $\begin{array}{l}\text { Quality } \\
\text { control }\end{array}$ \\
\hline $\begin{array}{l}\text { Cube } \\
\text { strength }\end{array}$ & M29 & 29 & 36.28 & 4.685 & 12.845 & Normal & $\begin{array}{l}\text { design } \\
\text { mix }\end{array}$ \\
\hline
\end{tabular}

Location: Middle/Edge panel

From equation (17),

$\delta_{x}=\left(\delta_{y}^{2}+0.0125\right)^{1 / 2}=0.189$

From equation (14),

$$
\begin{aligned}
& \mu_{x}=0.67 \times 22.18=14.861 \mathrm{~N} / \mathrm{mm}^{2} \\
& \sigma_{x}=14.861 \times 0.189=2.81 \mathrm{~N} / \mathrm{mm}^{2}
\end{aligned}
$$

From equation (20),

$$
F_{a}=0.34 \times 18=6.12 \mathrm{~N} / \mathrm{mm}^{2}
$$

Using equation (21),

$$
P_{f}=\phi\left(\frac{6.12-14.861}{2.81}\right)=\phi(-3.11)=9.3544 E-4
$$


Location: Staircase

Using equation (17),

$\delta_{x}=\left(\delta_{y}^{2}+0.0125\right)^{1 / 2}=0.190$

From equation (14),

$\mu_{x}=0.67 \times 17.56=11.76 \mathrm{~N} / \mathrm{mm}^{2}$.

$\sigma_{x}=11.76 \times 0.190=2.24 \mathrm{~N} / \mathrm{mm}^{2}$.

Using equation (20),

$f_{a}=0.34 \times 15=5.10 \mathrm{~N} / \mathrm{mm}^{2}$.

Using equation (21),

$P_{f}=\phi\left(\frac{5.1-11.76}{2.24}\right)=\phi(-2.97)=1.490 E-3$.

Location: Slab 2

Using equation (17),

$\delta_{x}=\left(0.1507^{2}+0.0125\right)^{1 / 2}=0.188$

From equation (14),

$\mu_{x}=0.67 \times 26.80=17.99 \mathrm{~N} / \mathrm{mm}^{2}$.

$\sigma_{x}=17.99 \times 0.188=3.38 \mathrm{~N} / \mathrm{mm}^{2}$.

Using equation (20),

$f_{a}=0.34 \times 20=6.8 \mathrm{~N} / \mathrm{mm}^{2}$.

Using equation (21)

$P_{f}=\phi\left(\frac{6.8-17.99}{3.88}\right)=\phi(-2.88)=1.99 E-3$

Location: Corner column

Using equation (17),

$\delta_{x}=\left(0.1245^{2}+0.0125\right)^{1 / 2}=0.125$

From equation (14),

$\mu_{x}=0.67 \times 30.28=20.29 \mathrm{~N} / \mathrm{mm}^{2}$.

$\sigma_{x}=20.29 \times 0.125=2.54 \mathrm{~N} / \mathrm{mm}^{2}$.

Using equation (20),

$f_{a}=0.34 \times 25=8.5 \mathrm{~N} / \mathrm{mm}^{2}$.

Using equation (21)

$P_{f}=\phi\left(\frac{8.5-20.29}{2.54}\right)=\phi(-4.64)=1.742 E-4$

Location: Middle column

Using equation (17),

$\delta_{x}=\left(0.12845^{2}+0.0125\right)^{1 / 2}=0.125$

From equation (14),

$\mu_{x}=0.67 \times 36.28=24.31 \mathrm{~N} / \mathrm{mm}^{2}$. 


$$
\sigma_{x}=0.125 \times 24.31=3.04 \mathrm{~N} / \mathrm{mm}^{2} \text {. }
$$

Using equation (20),

$f_{a}=0.34 \times 29=9.86 \mathrm{~N} / \mathrm{mm}^{2}$.

Using equation (21)

$$
P_{f}=\phi\left(\frac{9.86-24.31}{3.04}\right)=\phi(-4.76)=9.6796 E-5
$$

Using equation (13), the probability of failure of the structure is 0.00562 .

The safety index $(\beta)$ corresponding to the obtained value of probability of failure $(0.00562)$ is 2.54 .

\section{Discussion Of Results And Conclusion}

The results of safety analyses of an ongoing construction using failure mode superposition approach have been presented. The safety index obtained from formulated model was 2.54 which represents the upper bound value of safety index. The obtained safety index was compared with the code specified values for various structural members and was found to be less than 4.9 for beams in bending, 3.6 for beams in shear, 4.5 for slabs, and 3.9 for columns under dead-live load combination. In conclusion, the structure is not safe and can lead to uncommon accidents and damage of properties on collapse. The floor slab and beams are therefore recommended for careful demolition to give a new structural framework and supervision should be more stringent.

\section{References}

[1] Melchers, R. Structural Reliability Analysis and Prediction. Second Edition, John Wiley and Sons, 1999.

[2] Ranganathan, R. Structural Reliability, Analysis and Design, Jaico Publishing House, Mumbai, 1999

[3] Mori Y. and Ellingwood, B.R. Reliability-Based Service Life Assessment of Aging Concrete Structures. Journal of Structural Engineering, Vol. 119, No.5, 1993, pp. 1600-1621.

[4] Mori, Y. and Nonaka, M. LRFD for Assessment of Deteriorating Existing Structures. Structural Safety 32, 2001 , pp. $297-313$.

[5] Stewart, M.G. Time-Dependent Reliability of Existing RC Structures, Journal of Structural Engineering, No. 7, 1997 , pp. 896- 902.

[6] Afolayan, J.O. Cost-Effectiveness of Vibration Criteria for Wooden Floors, Asian Journal of Civil Engineering (Building and Housing), Vol. 5, Nos. 1-2, 2004, pp. 57-67.

[7] Villemeur, A. Reliability, Maintainability and Safety Assessment, Vol.2, (John Wiley), Chichester, 1992.

[8] Wilkinson, S. Physical Control of Risk, (Witherby), London, 1992.

[9] Freudenthal, A.M. Safety and Probability of Structural Failure, Transactions, ASCE, vol. 121, 1956, pp. 1337- 1375.

[10] Afolayan, J.O. Probability based design of glued thin-webbed timber beams, Asian Journal of Civil Engineering (Building and Housing) Vol. 6, Nos. 1-2, 2006, pp. 75-84

[11] Shehu M.B. Only enforcement and awareness will eliminate quackery in engineering. A speech published in NSE official magazine May, 2012, page 13 .

[12] BS: 81100 . British Standard Code of practice for Plain and Reinforced Concrete (3 ${ }^{\text {rd }}$ Revision) Indian Standards Institution, London, 1985, pp. 2-7.

[13] Sule S. Probabilistic Approach to Structural Appraisal of a Building During Construction. Nig. Journal of Tech., Vol. 30, No. 2, 2011, pp.149-153. 